\title{
Vol. 9, No. 1, 2015
}

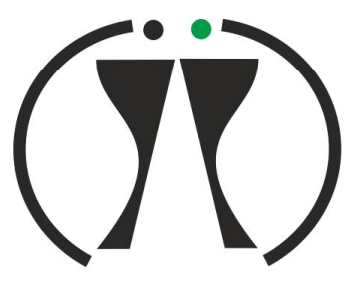

P R O B L E M S OF PSYCHOLOGY $\mathrm{IN} \bullet \mathrm{THE} 21 \mathrm{st}$ C E N T U R Y

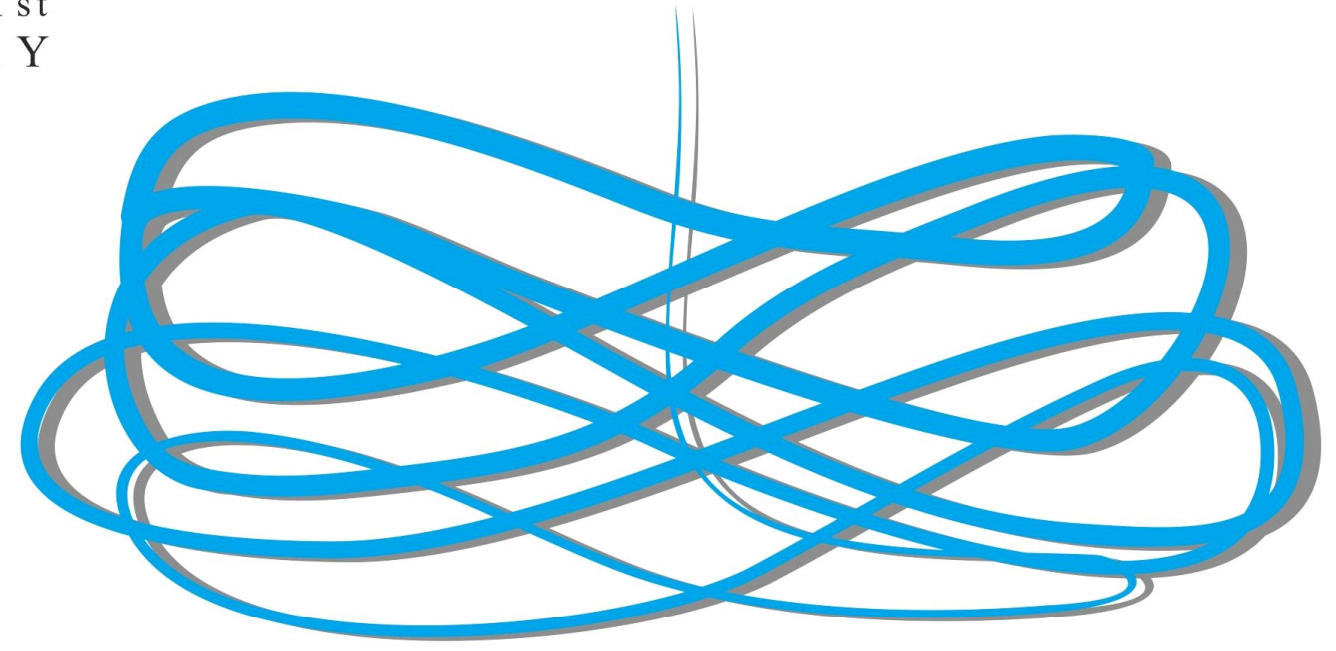

\section{PROBLEMS OF PSYCHOLOGY IN THE $21^{\text {ST }}$ CENTURY}

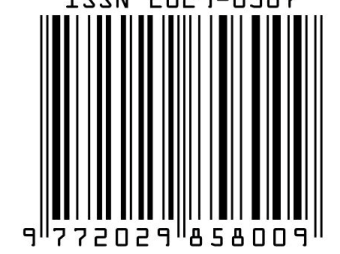


Vol. 9, No. 1, 2015

ISSN 2029-8587

\section{PROBLEMS OF PSYCHOLOGY IN THE 21'T CENTURY}

Scientia Socialis in Cooperation with Scientific Methodical Center „Scientia Educologica“, Lithuania,

The Associated Member of Lithuanian Scientific Society, Association of Lithuanian Serials (ALS), ESHS (European Society for the History of Science) and ICASE (International Council of Associations for Science Education)

The articles appearing in this scientific journal are indexed and abstracted in EBSCO: Discovery Service (EDS) (http://search.ebscohost.com), Copernicus Index (http://www.indexcopernicus.com),

Cabell Publishing, Inc., Directories of Academic Journals (http://www.cabells.com/index.aspx),

Contemporary Science Association/AAP databases

(http://www.contemporaryscienceassociation.net/journal/view/1207),

Social Psychology Network (http://www.socialpsychology.org/forums/addalink.htm),

Ulrich's Periodicals Directory (http://ulrichsweb.serialssolutions.com/login),

Open Academic Journals Index (OAJI) (http://oaji.net/journal-detail.html?number=444),

Global Impact Factor (GIF) (http://globalimpactfactor.com/problems-of-psychology-in-the-21st-century/), Scientific Indexing Services (SIS) (http://sindexs.org/JournalList.aspx?ID=1), Scientific Journal Impact Factor (SJIF) )http://www.sjifactor.inno-space.net/passport.php?id=18154), and Directory of Research Journal Indexing (DRJI) - http://www.drji.org/SearchDetails.aspx?JID=110 


\section{Publisher}

Scientia Socialis in Cooperation with Scientific Methodical Center „Scientia Educologica“, Lithuania, the Associated Member of Lithuanian Scientific Society, the Association of Lithuanian Serials, European Society for the History of Science (ESHS) and International Council of Associations for Science Education (ICASE)

\section{Editorial Board}

Dr., prof. Ferda Aysan, Dokuz Eylul University, Turkey

Dr., prof. Serhiy Boltivets, Grigory Kostyuk Psychological Institute of the Ukrainian National Academy of Pedagogical Sciences, Ukraine

Dr., assoc. prof. Irena Gailiene, SMC "Scientia Educologica", Republic of Lithuania

Dr., prof. Irakli Imedadze, Dimitri Uznadze Georgian Psychological National Society, Georgia

Dr. Julia Lakhvich, Belarusian State University, Republic of Belarus

Dr., prof. Vladimir S. Karapetyan, Armenian State Pedagogical University named after Kh. Abovyan, Armenia

Dr. Charles Kimamo, University of Nairobi, Kenya

Dr., assoc. prof. Vadim N. Kolesnikov, Karelian State Pedagogical Academy, Republic of Karelia, Russia

Dr., prof. Vincentas Lamanauskas, Scientific Methodical Centre „Scientia Educologica“, Republic of Lithuania (Editor-in-Chief)

Dr., assoc. prof. Jan Lašek, University of Hradec Kralove, Czech Republic

Dr., prof. Mary Anne Lauri, University of Malta, Malta

Dr., prof. Maria Ledzińska, University of Warsaw, Poland

Dr., prof. Aleksandr Lobanov, Belarusian State Pedagogical University, Republic of Belarus

Dr., assoc. prof. Tetiana M. Shyriaieva, National University of Ostroh Academy, Ukraine

Dr., assoc. prof. Stanislava Yordanova Stoyanova, South-West University "Neofit Rilski", Bulgaria

Dr., prof. Guna Svence, Riga Teacher Training and Educational Management Academy, Latvia Dr., assoc. prof. Yolanda Zografova, Institute for Population and Human Studies, Bulgarian Academy of Sciences, Bulgaria

Copyright of this issue is the property of Scientia Socialis, Lithuania. By virtue of their appearance in this open access journal, articles are free to use, with proper attribution, in educational and other non-commercial settings.

Problems of Psychology in the $21^{\text {st }}$ Century is an international, periodical, peer reviewed scientific journal, issued by the Scientia Socialis in cooperation with SMC „Scientia Educologica“.

\section{Address:}

Scientia Socialis, Donelaičio Street 29, LT-78115 Siauliai, Lithuania

E-mail: $\quad$ problemsofpsychology@gmail.com

Phone: $\quad+37068795668$

WEB page: http://www.jbse.webinfo.lt/PPC/Problems_of_Psychology.htm http://www.scientiasocialis.lt/ppc/ 